\title{
The Union of Three Muses: Literature, Choreography, Music in Russia's Ballet Productions in the Second Half of the 20th - Early 21st Centuries
}

\author{
Liudmila Mikheeva \\ Russian State Specialised Academy of Arts \\ Moscow, Russia \\ E-mail: lira191m@gmail.com
}

\author{
Magda Dzhichonaia \\ Russian State University named after A.N. Kosygin \\ Moscow, Russia \\ E-mail: magdalena-27@mail.ru
}

\begin{abstract}
The article deals with the issues of deep interrelation of fiction, choreography, music, which is vividly and distinctly embodied in ballet performances of Russia of the 20th - beginning of the 21st centuries. Fidelity to the traditions of classics and the courage of creative searches of artists have always distinguished the true masters of art. The ballet reveals the Russian world, created by our great literature, music. Creation of our choreographers not only and not so much "translate" works of fiction to the vocabulary of the ballet. They retain a deep philosophical meaning, ideas, thoughts of word artists. Literature, choreography, music in their forms cognize and transform the world, merging in a special synthetism traditional and innovative, implement the process of integrating various types of art.
\end{abstract}

Keywords-literature; choreography; music; ballet performances; mastery of choreographers; great Russian literature; integration of various types of art

\section{INTRODUCTION}

Art and life are closely connected. In a figurative form, symbolically, art reflects reality, gives information about people, their relationships, thoughts. Literature, choreography, music in a bright, metaphorical form, know the world, and attach people to the Beautiful. Literature in verbal form, choreography - in plastic, music - in sounds are designed to transform the world, merging in a special synthetism objective and subjective, national and international, traditional and innovative. In the choreography there is a process of integration of various types of art, in all the diversity of functions. The real world appears in the conventional generalized form in the literature, in music, and in choreography, evolving, embodying images and expressive in images, developing and improving the morphological structure, symbolism, artistic vocabulary. In any work of art the creative activity of many generations is concentrated. The artistic image, be it literature, choreography, music, always carries the universal features, "eternal" themes: life and death, light and darkness, good and evil, loyalty and betrayal, love, joy and hatred, grief. In all arts, in their structure the unity of psycho-physiological bases of human consciousness is manifested, general typological schemes are created.
Before the artists at the present stage, the task was to preserve and develop Russian culture with the utmost urgency, the need to develop a concrete concept, a creative platform connected with a careful attitude to traditions. There are tasks to restore ethical mechanisms that regulate relations within the community, including - the embodiment of the ideals of folk art, reflecting the picture of man's poetic world. Preservation of the continuity of generations is impossible without studying the historical and cultural past of Russia, without educating the youth on our rich traditions. This means the formation of a sense of national pride, patriotism and citizenship.

The classics are always modern, masterpieces of art still excite people, because each era, different generations read them in different ways, in accordance with the ideals of their time, but masterpieces and classics live forever. The theater and ballet are syncretic, especially if we turn to choreographic performances inspired by the great works of literature of our great writers.

\section{THE EMPIRICAL RESEARCH METHODOLOGY}

Methodology of empirical research based on research methods: historical-cultural, historical-functional, typological, holistic analysis of the artistic text (including choreographic vocabulary), as well as a comparativetypological method. We have in mind the synthesis of existing literary research methods and those innovative techniques that allow analyzing choreographic poetics.

Let's turn to the choreographic Pushkinian. During the 20th century, ballets were inspired, inspired by Pushkin's works. No writer had as many ballets staged in his works as in Pushkin. These ballets entered the golden fund of our art, determined the main trends of Russian choreography, contributed to the formation of a new choreographic aesthetics and vocabulary. This is exactly what determines the school of Russian classical ballet. In such ballets as "Ruslan and Lyudmila", "The Prisoner of the Caucasus", "The Fountain of Bakhchisarai", "The Gypsies", "The Bronze Horseman", "The Stone Guest", ballets on Pushkin fairy tales - "On the Dead Princess and the Seven Knights" "The Tale of the Priest and the Worker of his Balda" - there 
is a clear and clear connection between the choreographic aesthetics and the beautiful works of Pushkin. We see here the harmony of art, the fidelity to the traditions of the classics of the Russian ballet and something new, without which the development of art is impossible.

In July 2013 on the stage of the Bolshoi Theater the premiere of the ballet "Onegin" by John Crenco took place. Boris Eifman also staged the ballet "Onegin". His "Onegin" Crenco was first staged in 1965. This ballet is not a choreographic transcription of the plot of the novel in Pushkin's verse to the music of Tchaikovsky's opera. It is like a separate work, it is collected from fragments of Tchaikovsky's works. As noted by modern critics (for example, Anna Platonova), the basis of the concept of ballet Crenco is gradation: from pastel idyll to secular tragedy. Constantly changing scenery: the landscape with birches: a wooden house in the Larin estate, the luxury of the ball room in St. Petersburg, the boudoir of Tatyana Princess. In music, tension is growing, the plasticity of the dancers is changing, conveying the life of the characters: in a dream and in reality. The choreographer in his own way sculpts all familiar and beloved images, although Tatyana is given absolutely in the traditions of Pushkin's ideal. The plot of the novel in verse is retold by the choreographer, it uses the principle of a mirror composition: the characters write letters to each other; a mirror is present and in a literal sense. There are also such impossible for the Russian viewer moments, as the divination of Tatiana and Olga on the mirror in the day and summer (?!)

The ballet is based on the poem "The Bronze Horseman" (we note that Pushkin defines the genre of the poem as "The Petersburg Story") was staged in 2013 at the Mariinsky Theater. The premiere took place long ago on the stage of the Bolshoi Theater - June 27, 1949 (on the occasion of the 150th anniversary of the birth of Pushkin), music by R. Gliere, production by R. Zakharov. In St. Petersburg (then Leningrad) - in the Theater. CM. Kirov (Mariinsky Theater). It was "a philosophical spectacle of a wide epic sound" [1]. Previously, Pushkin's creation was never put on stage. Pushkin has an epic, a peculiar philosophy combined with lyrics, history - with everyday life. Choreographer R. Zakharov carefully studied materials relating to Pushkin's Petersburg and Peter's epoch, he worked in archives. R. Zakharov stressed that in Pushkin's poem he was primarily attracted by the Russian patriotic theme and philosophical content. The composer R. Glier expressed his creative enthusiasm for the work: "The idea to write the ballet" The Bronze Horseman "immediately captivated me ... The introduction of new scenes -"Port" and "Assembly" allowed to expand the dance side, to give various Russian dances. This greatly enriched the ballet ... At first in the ballet dance music prevails, in the second half - symphonic" [2]. The musical drama is harmonious, it is an example of loyalty to the traditions of the Russian symphonic school.

The tragic theme of the protagonist Eugene is woven into a wide canvas, a major anthem to the great city. R. Glier skillfully used the intonation of Russian song and dance folklore. In the ballet - and the classical adagio, and variations, and household historical dances, and folk dances, dances. Waltz, waltz themes occupy a significant place. The historical personality is shown on the stage - Peter I. The male dance of Peter is a special plastic score. A bright plastic pattern resembles the famous picture of V. Serov "Peter I" a wide, rapid step. The image of Eugene is complicated psychologically, requires subtle nuances. In Pushkin's poem in the Introduction - a hymn to Peter the Transformer, but he eventually became a symbol of that power that is alien and hostile to the people. He is an "idol on a bronze horse"; in a delirious state, Eugene, horrified, sees that this idol is chasing him: "As if a thunder roar, a heavy-heave jumping over a shaken pavement." The abundance of alliterations perfectly conveys this heavy run of the brass rider. The clash between Peter (power) and Eugene (a small man) is the triumph of the general over the private. "The Bronze Horseman" is first and foremost the Russian ballet epic spectacle, the apotheosis of national power, genius, beauty" [3]. We see a fusion of classics and folk dance. Episodes of the ballet convey the rhythm, the dynamics of Pushkin's verse. The tragic scenes of the mad Eugene are related to the fortunes of the ballet. The image of Parasha is in the traditions of Pushkin: a pure, chaste girl.

"The Bronze Horseman" is the most complex work of ballet Pushkin's, an undeniable success in the embodiment of the Pushkin theme on the ballet stage. In the Soviet years the ballet was staged, except Moscow and Leningrad, in Tashkent, Saratov, Lvov, Yerevan, Novosibirsk, Alma-Ata, and Odessa.

And now at the Mariinsky Theater he was set at the opening of the XVI International Ballet Festival "Mariinsky". Actively used modern special effects (for example, video projection, all kinds of projections on the curtain). Consider the great success of the production of creating a flood effect. The play lives, filling with a new power. I want to believe that it is as eternal as the creations of the great Pushkin are eternal.

Soviet ballet Pushkinian began with the creation of performances on the themes of "southern poems." These are romantic works, whose heroes are sublime and noble, in their destinies raging passions. This is what gives the choreographer opportunities for the plastic embodiment of the characters of the Pushkin heroes. The ballet "Bakhchisarai Fountain" became a stage performance for our choreography. The author of the music, composer B. Asafyev said: "The exceptional realism of Pushkin's poem, amazing acuity and receptivity, along with emotional immediacy make it possible to return the life stimulus to the ballet classics. I believe that through the Pushkin image the classical ballet will soon come to the present "[4]. The ballet, called a choreographic poem in four acts, was staged by R. Zakharov; premiere took place at the Opera and Ballet Theater. CM. Kirov (now again - the Mariinsky Theater) on September 28, 1934, and at the Bolshoi Theater - June 11, 1936. Let us emphasize once again that all the "southern poems" of Pushkin are romantic in spirit and means of expression, their characters are full of excited and passionate human feelings. In the play, a deep historical and philosophical conflict was handed over. The great master of choreographic art A. Vaganov noted: "Classical dance is a 
form of expression in the movement of human emotions. It is the poetry of the human movement, like music, like the song" [5]. The classical dance vocabulary was reinterpreted in a new way, with the help of which a truly dramatic action was achieved, combined with an accurate psychological development of images revealing the deep thoughts of Pushkin's poem. The author of the libretto, playwright and theatrical critic N.D. Volkov outlined a new style of staging literary works, he did not mechanically retell the content of the poem, but creatively reworked, preserving the idea and the philosophical essence of the original source. In the libretto, he, relying on hints and sketches of dramatic situations in Pushkin's poem, dramatically develops the main conflict: the clash of the world of Mary and the world of Khan Girey, a world of high spiritual culture and a world of violence and servility. To this end, Polish scenes were introduced in the play, connected with the sublime love of Wenceslas and Mary, they are contrasted with the wild passion of Girei, the harem world in which Zarema lived. At the heart of B. Asafyev's music is a reflection on the philosophical theme of the work, about the personality of the poet, about the essence of romanticism. Hence the successful interlacing of symphonic episodes, romantic background, musical intonations of the Pushkin era. At the beginning and at the end of the ballet, the melody of the song of Gurilev on Pushkin's verses was heard:

The fountain of love, the fountain alive!

I brought you two roses,

\section{I love your voice}

\section{And poetic tears.}

Melody framed the action of the ballet. The image of the weeping fountain, erected by Girei in honor of Mary, lives in the music of the ballet. Great was the main acting potential of the first performers of parties: G. Ulanova and $\mathrm{K}$. Sergeyev, and later - M. Plisetskaya. The setting then of the young choreographer Rostislav Zakharov of the "Bakhchisarai Fountain" led to the creation of a new genre-a ballet-play with his literary centrism. It was a drama ball, and the actors - ballerinas and dancers - began to pay close attention to the purely actor's work on the role, to the period that the directors call "table music", with the analysis of characters and conflicts.

In 2015, the Bolshoi Theater staged the ballet "Hero of Our Time" for the novel of the same name $\mathrm{M}$. Yu. Lermontov.

The tandem was unusual: the choreographer and director (respectively: J. Posokhov and K. Serebrennikov); composer - I. Demutsky. An unusual idea was the "multiplicity" of Pechorin: there were three of them at once - in "Bela", "Taman" and "Princess Mary". This idea can be justified by the fact that in every novel in the novel Pechorin is seen from different angles, through the eyes of different people: mountaineers, "honest" smugglers, Maxim Maksimych and fleetingly - the author-narrator. Lermontov does this consciously, as well as what he changes, breaks the chronology, external events for the sake of the logic of development of the character of the protagonist, which should have been adequately understood by the reader, i.e. not as a villain, but the victim of his time, the generation of the 40s of the XIX century, about the spiritual drama of which Lermontov said in the poem "Duma": "I am sad to look at our generation." They were people, with their "feeling and mind boiling in action empty", i.e. Those who will be called "superfluous people". Therefore, in the ballet three Pechorin: Igor Tsvirko (in "Bel"), Artem Ovcharenko (in "Taman") and Ruslan Skvortsov (in "Princess Mary"). The plasticity of the actors is the same, but such strokes as sharply upturned hands, strong jumps are meant to shade the "different" Pechorins in different circumstances. Scenic space and scenery are very unusual: in the "Bel" - a rock wall, which "fences" the cabinet of Pechorin from the world of the highlanders. In the "Taman" viewers see the boat pier, on the back of the stage "the sea shines." In "Princess Mary" in front of us is a ward with simulators for wounded soldiers, then a dance school, then a barracks. Duel Pechorin with Grushnitsky takes place on the windowsills with windows open on both sides. With all these innovations, the ballet correlates with the Russian tradition of classics. Modern details - in wheelchair invalids as wounded soldiers who are being treated in Pyatigorsk. Critics point out the "sensitive plasticity of Denis Savin" - Grushnitsky, the virtuosity of the ballerinas: S. Zakharova (Mary), E. Shipulina (Undine), K. Kretova (Vera).

The real event was the premiere of the ballet Anna Karenina at the Bolshoi Theater. The choreographer is John Neumeier. He created a plot performance, transferred the action in our days, to an uncertain place, and in general rethought the plot. Karenin (S. Chudin) - "politician", preparing for re-election; Vronsky (D. Rodkin) - athlete and military at the same time; Steve Oblonsky (M. Lobukhin) - a rich playboy in jeans; Dolly (A. Stashkevich) - housewife with 6 children; Levin (D. Savin) - a cowboy from Iowa, riding a tractor on stage (?!); Anna (S. Zakharova) - a lady in a fashionable modern dress; "Child", overgrown child (Grigory Ikonnikov); Kitty (D. Khokhlov). The transfer of action (modern chronotope) is a "routine" practice in a musical theater. Neumayer, just like B. Eifman, does a lot in his own way. Ignorance of our realities, the novel of L.N. Tolstoy choreographer can justify the artist's right to selfexpression. We are not even sure that the action takes place in Russia. The choreographer claims that the ideas of the novel as masterpieces are relevant at all times. Choosing Neumeier's music: Tchaikovsky, Schnittke and Cat Stevens. Everything reminds us of our time (here you can argue with the deliberateness of situations): a rally of supporters Karenina with his electorate, with posters in French; mise en scene with dances (Karenin, Anna, sonny). A lot of symbols: the doors in the decorations; Supremacism on the walls of Anna's house; a locomotive of a child, who drives along the proscenium. The level of the ballet dancers is great, they help to raise the spectacle to the philosophical level - at all times.

Outstanding choreographer of the second half of the 20th century B. Eiffman created the ballet "The Brothers Karamazov", referring to the novel of the same name F.M. Dostoevsky, who is the pinnacle of the writer's philosophical quest. The performance develops the traditions of 
psychological ballet art; this is something reminiscent of the "plastic equivalent" of Dostoyevsky's genius, which was opened to the torment of the destructive passions. The choreographer uses the means of classical dance vocabulary to explore the moral catastrophe of the Karamazovs, the deep essence of human nature, where "the devil fights with God." If there is no God, then everything is permitted. Eifman, from the standpoint of modernity, asks the question: what if there is a God and everything is allowed? As in today's conditions, to find the path to happiness, to find harmony, faith, how to overcome the power of vice, how to find ourselves in a crumbling world? The choreographer tries to help the viewer to find answers to these questions. What is the essence of being? The legend of the Grand Inquisitor: well-fed obedience is good? Or freedom of spirit? Is it possible to find a way to redemption of sin? It is important that these issues are raised, and it is up to our contemporaries to solve them.

To our "eternal" A.P. Chekhov choreographers are repeatedly addressed. So, since 1986 there has been a ballet "Anyuta" (the story "Anna on the neck"); music by V. Gavrilin, director V. Vasilyev. The premiere was on the stage of the Bolshoi Theater. Lyricism and comedy (even grotesqueness in the scene with officials in the ministry "anthem of the bureaucracy") perfectly convey the subtle Chekhov atmosphere. And on the stage of the Musical Theater in 2017 a two-act ballet "The Cherry Orchard" was presented, with modern choreography based on the classical. In the performance, the choreographer S. Mikel included the original line - "souls of cherry trees" (in Chekhov the image of the cherry garden itself is a symbol of the Motherland, which will be reborn in the future, as the author was sure). Chekhov has a comedy; a choreographer has a tragedy. Used music G. Sviridov ("Snowstorm", "Little Triptych", suite "Time, Forward!"), As well as music by O. Khodosko, ekosez from "Eugene Onegin" P.I. Tchaikovsky.

One cannot help but dwell on the choreographic fantasy on the themes of M. Bulgakov's novel Master and Margarita. Composer - A. Petrov, ballet master - B. Eifman. The premiere took place on February 27, 1987 on the stage of the October Hall in Leningrad. The music of the ballet was born from the same symphony by A. Petrov. It impresses with power, tragedy, bright theatricality, sharp rhythms. The choreographer did not try to completely reflect the plot and the problems of Bulgakov's novel. This is an independent work; the characters and events are seen with different eyes. From the ballet "gone" humor and bitter laughter, genre scenes. In the main, ballet and novel are one. Moral foundations, their strength and powerlessness in modern times; the greatness of sacrificial love (Margarita), inquisitiveness of infernal Woland; the theme of the creative destiny of the artist and the freedom of his work. In the center of events in the play is the figure of Woland. This is not Bulgakov's Woland, it's not so much an "evil of nature" as nature itself, life, with its good and cruelty. He interferes with all events.

But the main theme of the ballet is the fate of the Master. His fate is tragic, he is forced to remain silent (on stage he appears with a tightly tied mouth). Actors who perform the roles of Margarita, Master, Pilate, Woland, perfectly master the language of modern plastics. The imaginative world of the play is enriched by a successful scenography ( $T$. Murvanidze): a white-gray tent, with a black hole in the middle; The tent is made up of many "pages" of a certain manuscript. The leaves illuminate for a moment with a flame, but the flame goes out - the manuscripts do not burn.

\section{EVALUATION}

The works of our classical literature in the ballet revealed the Russian world. Our choreography, despite the fact that this art of "conventional" beauty, always drew inspiration from the actual themes of modern life. Romantic heroes, inspired by Pushkin's works, Dostoevsky's heroes are swept by the heroes, tragic characters LN. Tolstoy, with their search for truth, love, refined Chekhovian natures - all these are people living in a world of fiery passions, the bearers of national traits, the mysterious Russian soul, and this is what the creations of the choreographers show us. This is not just a "translation" of works of fiction into the language of ballet. The main thing is the preservation of the idea, the style of the literary sources, the thoughts of the artist.

\section{CONCLUSION}

Pushkin's, as well as the philosophical novels of Dostoevsky, LN. Tolstoy, the works of Chekhov, Bulgakov became the property of world choreographic art. All this contributes to the development of dialogues and polylogues, which helps the full-blooded life of art, its development.

A careful attitude to traditions and the courage of innovative searches - without this art cannot simply exist. The interpretation of classical images depends on the desire of the choreographer in a new way, in accordance with his time to look at the masterpieces. This is their great historical role, the approach to modernity. The mastery of the classics of fiction goes along the lines of musical and dance symphonism, and in this lies the pledge of new accomplishments of all kinds and genres of art.

\section{REFERENCES}

[1] N. Elyash, Pushkin and the ballet theater. M., The art, 1970.

[2] Ibidem, p. 247.

[3] Ibidem, p. 249.

[4] B. Asafiev, Soviet Art, September 29, 1934.

[5] Izvestia newspaper, June 22, 1935.

[6] A.V. Veslov, Russian theater on the scrapping of eras. The turn of the XX-XXI centuries. M., University Book, 2009.

[7] Pushkin in the memoirs of contemporaries. M., Goslitizdat, 1950.

[8] G. Ulanova, Poetry in the dance. "Theater" 1949, No. 6. 